\title{
Surface Protection of Carbon Steel by Hexanesulphonic Acid-Zinc Ion System
}

\author{
C. Mary Anbarasi ${ }^{1}$ and Susai Rajendran ${ }^{2,3}$ \\ ${ }^{1}$ PG Department of Chemistry, Jayaraj Annapackiam College for Women, Periyakulam 625601, India \\ ${ }^{2}$ Corrosion Research Centre, PG and Research Department of Chemistry, GTN Arts College, Dindigul 624005, India \\ ${ }^{3}$ Department of Chemistry, RVS School of Engineering and Technology, Dindigul 624005, India
}

Correspondence should be addressed to C. Mary Anbarasi; anbuc_m@yahoo.co.in

Received 24 December 2013; Accepted 2 February 2014; Published 19 March 2014

Academic Editors: K. N. Allahar, L. Bazzi, A. Hermann, and B. Normand

Copyright (c) 2014 C. M. Anbarasi and S. Rajendran. This is an open access article distributed under the Creative Commons Attribution License, which permits unrestricted use, distribution, and reproduction in any medium, provided the original work is properly cited.

\begin{abstract}
Inhibition of corrosion of carbon steel in dam water by hexanesulphonic acid as its sodium salt $\mathrm{C}_{6} \mathrm{H}_{13} \mathrm{SO}_{3} \mathrm{Na}$ (SHXS) in the absence and presence of a bivalent cation zinc ion $\left(\mathrm{Zn}^{2 \mathrm{~b}}\right)$ has been investigated using weight loss method. Results of weight loss method indicate that inhibition efficiency (IE) increased with increase of inhibitor concentration. Polarization study reveals that SHXS-Zn ${ }^{2+}$ system controls the cathodic reaction predominantly. AC impedance spectra reveal that a protective film is formed on the metal surface. The nature of the metal surface has been analysed by Fourier Transform Infrared Spectroscopy (FTIR) and Atomic Force Microscopy (AFM).
\end{abstract}

\section{Introduction}

Corrosion is a naturally occurring phenomenon which deteriorates a metallic material or its properties because of a reaction with its environment. Corrosion can cause dangerous and expensive damage to everything from pipelines, bridges, and public buildings to vehicles, water, and wastewater systems, and even home appliances. It is one of the most serious problems in the oil and gas industry. The use of organic inhibitors is one of the most widely practical methods for protection of metals and alloys against corrosion. The efficiency of an organic compound as a corrosion inhibitor is closely associated with the chemical adsorption [1-4]. Most well-known organic inhibitors contain nitrogen, sulfur, and oxygen atoms due to their ability to form an adsorbed protective film at the metal/media interface. Studies report that the adsorption of organic inhibitors mainly depends on some physicochemical properties of the molecule, related to its functional groups, to the possible steric effects and electronic density of donor atoms: adsorption is supposed also to depend on the possible interaction of P-orbitals of the inhibitor with d-orbitals of the surface atoms, which induce greater adsorption of the inhibitor molecules onto the surface of carbon steel, leading to the formation of a corrosion protective film [5].

A survey of the available literature reveals that the corrosion inhibition of 2-naphthalenesulfonic acid, 2, 7naphthalenedisulfonic acid, and 2-naphthol-3, 6-disulfonic acid on Armco-iron electrode in sulfuric acid has been investigated by Vračar and Draži. The inhibition efficiency changes with the number of functional groups substituted on the benzene ring and increases with concentration [6]. The inhibition action of 2-mercaptobenzoxazol, 2-mercapto benzimidazole, $\mathrm{N}$-cetyl pyridinium bromide, and propargyl benzene sulphonate on the corrosion of carbon steel in acid media has also been studied by Prakash et al. The corrosion inhibitors are used to reduce corrosion damage in subsurface equipment in oil well fields. The corrosion inhibition activity was studied by gravimetric and potentiostatic polarization methods in presence of $20 \% \mathrm{HCl}$ [7]. Manickavasagam et al. have reported the corrosion inhibition of poly(Styrene sulphonic acid) - doped polyaniline on carbon steel in acid media. The polymer acts as an anodic inhibitor. The adsorption of the compound on the metal surface obeys Temkin's 
adsorption isotherm [8]. Aliev has described the influence of salts of alkyl phenol sulphonic acid on the corrosion of ST3 steel. The protective effect increases with temperature. The investigated compounds inhibit corrosion of ST3 steel as a result of chemical adsorption [9]. Shakkthivel and Vasudevan have studied the effect of acrylic acid-diphenylamine sulphonic acid copolymer as threshold inhibitor for sulphate and carbonate scales in cooling water systems. The results show that the polymer acts as a very good antiscaling inhibitor both in the carbonate and sulphate brines. Copolymer of acrylic acid-diphenylamine sulphonic acid can be used safely in cooling water systems [10]. Perusal of several literatures reveals that there is no information regarding the use of hexanesulphonic acid (SHXS) in combination with zinc ion $\left(\mathrm{Zn}^{2+}\right)$ as corrosion inhibitor. This paper focuses on the IE of hexanesulphonic acid as its sodium salt (SHXS) in controlling corrosion of carbon steel immersed in dam water in the absence and presence of $\mathrm{Zn}^{2+}$. The investigation is performed using weight loss method, polarization technique, and $\mathrm{AC}$ impedance spectroscopy. The morphology of the protective film was examined by FTIR and AFM techniques.

The medium which is used in the present study is dam water collected from Sothuparai dam in the state of Tamil Nadu, India, constructed across the Vaigai River, the water from which is used in cooling systems by the industries located downstream.

\section{Experimental Method}

The chemicals used in this study, sodium hexanesulphonate (inhibitor) and $\mathrm{ZnSO}_{4} 7 \mathrm{H}_{2} \mathrm{O}\left(\mathrm{Zn}^{2+}\right.$ ions) coinhibitor, were AR grade.

2.1. Preparation of the Specimen. Carbon steel specimens of size $1.0 \mathrm{~cm} \times 4.0 \mathrm{~cm} \times 0.2 \mathrm{~cm}$, area $10 \mathrm{~cm}^{2}$, and chemical composition $0.026 \%$ sulphur, $0.06 \%$ phosphorous, $0.4 \%$ manganese, $0.1 \%$ carbon, and the rest iron (density $7.87 \mathrm{gm} / \mathrm{cm}^{3}$ ) were polished to a mirror finish and degreased with trichloroethylene and used for the weight loss method and surface examination studies.

2.2. Weight Loss Method. Carbon steel specimens were immersed in $100 \mathrm{~mL}$ of the medium containing various concentrations of the inhibitor (sodium hexanesulphonate) in the absence and presence of $\mathrm{Zn}^{2+}$ for 3 days. The weights of the specimens before and after immersion were determined using a Digital Balance (Model AUY 220 SHIMADZU). The corrosion products were cleaned with Clarke's solution prepared by dissolving 20 gms of $\mathrm{Sb}_{2} \mathrm{O}_{3}$ and 50 gms of $\mathrm{SnCl}_{2}$ in one litre of Conc. $\mathrm{HCl}$ of specific gravity (1.9) [11]. The corrosion IE was then calculated using the equation

$$
\mathrm{IE}=100\left[1-\left(\frac{W_{2}}{W_{1}}\right)\right] \%,
$$

where $W_{1}$ is the weight loss value in the absence of inhibitor and $W_{2}$ is the weight loss value in the presence of inhibitor.
Corrosion rate was calculated using formula [12] millimeter per year

$$
(\mathrm{mm} / \text { year })=\frac{87.6 \mathrm{~W}}{D A T} .
$$

$W=$ weight loss in milligrams, $D=$ density of specimen in $\mathrm{g} / \mathrm{cm}^{3}, A=$ area of specimen in $\mathrm{cm}^{2}$, and $T=$ exposure time in hours.

2.3. Potentiodynamic Polarization. Polarization studies were carried out in a $\mathrm{CHI}$-electrochemical work station with impedance model 660A. It was provided with iR compensation facility. A three-electrode cell assembly was used. The working electrode was carbon steel. Saturated calomel electrode was the reference electrode. Platinum was the counter electrode. From polarisation study, corrosion parameters such as corrosion potential $\left(E_{\text {corr }}\right)$, corrosion current $\left(I_{\text {corr }}\right)$, Tafel slopes anodic $=b_{a}$, and cathodic $=b_{c}$ were calculated and linear polarization resistance (LPR) was also calculated. The scan rate $(V / S)$ was 0.01 . Hold time at $\mathrm{Ef}(\mathrm{s})$ was zero and quiet time was two seconds.

2.4. AC Impedance Spectra. The instrument and cell set-up used for polarization study was used to record AC impedance spectra also. The real part $\left(Z^{\prime}\right)$ and imaginary part $\left(Z^{\prime \prime}\right)$ of the cell impedance were measured in ohms at various frequencies. Values of charge transfer resistance $\left(R_{t}\right)$ and the double layer capacitance $\left(C_{\mathrm{dl}}\right)$ were calculated:

$$
R_{t}=\left(R_{s}+R_{t}\right)-R_{s}
$$

where $R_{s}=$ solution resistance

$$
C_{\mathrm{dl}}=\frac{1}{2} \pi R t f_{\max }
$$

where $f_{\max }=$ frequency at maximum imaginary impedance.

AC impedance spectra were recorded with initial $E_{(v)}=$ 0 , high frequency $(\mathrm{Hz})=1 \times 10^{5}$, low frequency $(\mathrm{Hz})=1$, amplitude $(\mathrm{V})=0.005$, and quiet time $(\mathrm{s})=2$.

2.5. Surface Examination Study. The carbon steel specimens were immersed in various test solutions for a period of 1 day. After immersion, the specimens were taken out and dried. The nature of the film formed on the surface of the metal specimen was analyzed by various surface analysis techniques.

2.5.1. Fourier Transform Infrared Spectra (FTIR). These spectra were recorded in a Perkin-Elmer-1600 spectrophotometer using $\mathrm{KBr}$ pellet. The FTIR spectrum of the protective film was recorded by carefully removing the film, mixing it with $\mathrm{KBr}$ and making the pellet.

2.5.2. Atomic Force Microscopy Characterization (AFM). The carbon steel specimens immersed in blank and in the inhibitor solution for a period of one day were removed, rinsed with double distilled water, dried, and subjected to 
TABLE 1: Water analysis.

\begin{tabular}{lc}
\hline Parameters & Result \\
\hline Appearance & Brownish \\
Total dissolved solids & $100 \mathrm{~mol} / \mathrm{L}$ \\
Electrical conductivity & $140 \mu \mathrm{S} / \mathrm{cm}$ \\
$\mathrm{pH}$ & 8.25 \\
Total hardness as $\mathrm{CaCO}_{3}$ & $50 \mathrm{~mol} / \mathrm{L}$ \\
Calcium & $10 \mathrm{~mol} / \mathrm{L}$ \\
Magnesium & $06 \mathrm{~mol} / \mathrm{L}$ \\
Iron & $1.2 \mathrm{~mol} / \mathrm{L}$ \\
Nitrate & $10 \mathrm{~mol} / \mathrm{L}$ \\
Chloride & $10 \mathrm{~mol} / \mathrm{L}$ \\
Sulphate & $02 \mathrm{~mol} / \mathrm{L}$ \\
\hline
\end{tabular}

TABLE 2: The corrosion inhibition efficiencies and the corresponding corrosion rates (mm/year) of SHXS- $\mathrm{Zn}^{2+}$ system.

\begin{tabular}{lcccccc}
\hline $\begin{array}{l}\text { Inhibitor } \\
\text { SHXS } \\
(\mathrm{mol} / \mathrm{L})\end{array}$ & \multicolumn{7}{c}{$\mathrm{Zn}^{2+}(\mathrm{mol} / \mathrm{L})$} \\
$\times 10^{-3}$ & IE & CR & \multicolumn{2}{c}{$5.2 \times 10^{-5}$} & \multicolumn{2}{c}{$1.04 \times 10^{-4}$} \\
& $\%$ & IE & CR & IE & CR \\
\hline 0 & - & 0.1127 & 12 & 0.0992 & 21 & 0.0890 \\
0.27 & 10 & 0.1014 & 26 & 0.0834 & 57 & 0.0642 \\
0.54 & 13 & 0.0981 & 29 & 0.0801 & 64 & 0.0721 \\
0.81 & 19 & 0.0913 & 32 & 0.0766 & 71 & 0.0327 \\
1.08 & 26 & 0.0834 & 36 & 0.0721 & 74 & 0.0293 \\
1.35 & 31 & 0.0778 & 40 & 0.0676 & 83 & 0.0192 \\
\hline
\end{tabular}

the surface examination. Atomic Force Microscope (Veeco diInnova model) was used to observe the samples' surface in tapping mode, using cantilever with linear tips. The scanning area in the images was $5 \mu \mathrm{m} \times 5 \mu \mathrm{m}$ and the scan rate was $0.6 \mathrm{~Hz}$.

\section{Results and Discussion}

3.1. Analysis of Weight Loss Study. The physicochemical parameters of dam water are given in Table 1.

Inhibition efficiency (IE) and the corrosion rates in millimeter per year ( $\mathrm{mm} /$ year) of carbon steel immersed in dam water in presence of SHXS- $\mathrm{Zn}^{2+}$ system for a period of 3 days are given in Table 2.

It is found that the IE increases as the concentration of SHXS increases. As the concentration of $\mathrm{Zn}^{2+}$ increases, IE also increases. A synergistic effect exists between SHXS and $\mathrm{Zn}^{2+}$. For example, $1.35 \times 10^{-3} \mathrm{~mol} / \mathrm{L}$ of SHXS has $31 \% \mathrm{IE}$. $1.04 \times 10^{-4} \mathrm{~mol} / \mathrm{L}$ of $\mathrm{Zn}^{2+}$ has $21 \%$ IE. However, interestingly the formulation consisting of $1.35 \times 10^{-3} \mathrm{~mol} / \mathrm{L}$ of SHXS and $1.04 \times 10^{-4} \mathrm{~mol} / \mathrm{L}$ of $\mathrm{Zn}^{2+}$ has $83 \%$ IE. That is, the mixture of inhibitors shows better IE than the individual inhibitors. The improvement in the protection efficiency can be attributed to the formation of a complex between $\mathrm{Zn}^{2+}$ and SHXS which results from the synergistic effect between the two inhibitors,
TABle 3: Synergism Parameter $\left(S_{I}\right)$.

\begin{tabular}{lccccc}
\hline \multirow{2}{*}{$\begin{array}{l}\text { SHXS } \\
(\mathrm{mol} / \mathrm{L}) \times 10^{-3}\end{array}$} & $I_{1}$ & \multicolumn{2}{c}{$\begin{array}{c}\text { SHXS-Zn } \\
\left(5.2 \times 10^{-5}\right)\end{array}$} & \multicolumn{2}{c}{$\begin{array}{c}\text { SHXS-Zn } \\
2+\end{array}$} \\
& & $I_{(1+2)}^{\prime}$ & $S_{I}$ & $I_{(1+2)}^{\prime}$ & $S_{I}$ \\
\hline 0.27 & 0.10 & 0.26 & 1.0703 & 0.57 & 1.6535 \\
0.54 & 0.13 & 0.29 & 1.0783 & 0.64 & 1.9090 \\
0.81 & 0.19 & 0.32 & 1.0482 & 0.71 & 2.2066 \\
1.08 & 0.26 & 0.36 & 1.0175 & 0.74 & 2.2485 \\
1.35 & 0.31 & 0.40 & 1.0120 & 0.83 & 3.2065 \\
\hline
\end{tabular}

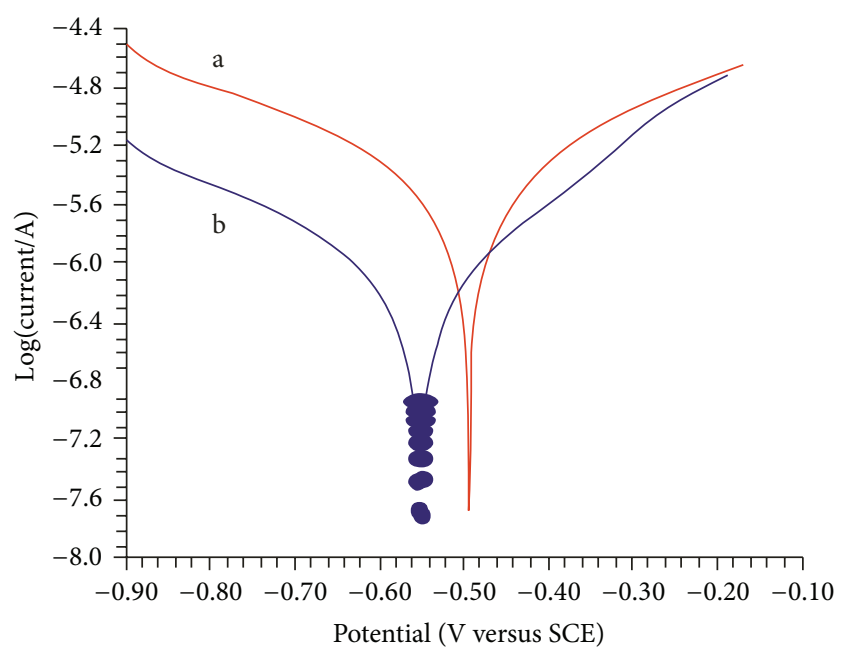

FIGURE 1: Polarisation curves of carbon steel immersed in various test solutions. (a) Dam water. (b) Dam water containing $1.35 \times$ $10^{-3} \mathrm{~mol} / \mathrm{L}$ of SHXS and $1.04 \times 10^{-4} \mathrm{~mol} / \mathrm{L}$ of $\mathrm{Zn}^{2+}$.

$\mathrm{Zn}^{2+}$ and SHXS. As a result of this complex formation, the inhibitor molecules are readily transported from the bulk to the metal surface [13].

Synergism Parameter $\left(S_{I}\right)$. Synergism parameters are indications of synergistic effect existing between inhibitors [14, 15]:

$$
S_{I}=\frac{1-I_{1+2}}{1-I_{1+2}^{\prime}},
$$

where $I_{1+2}=\left(I_{1}+I_{2}\right)-\left(I_{1} I_{2}\right), I_{1}=$ surface coverage of inhibitor (SHXS), $I_{2}=$ surface coverage of inhibitor $\left(\mathrm{Zn}^{2+}\right)$, and $I_{1+2}^{\prime}=$ combined surface coverage of inhibitors (SHXS) and $\left(\mathrm{Zn}^{2+}\right)$

$$
\text { Surface coverage }=\frac{\mathrm{IE}}{100} \text {. }
$$

$I_{2}$ for $\mathrm{Zn}^{2+}\left(5.2 \times 10^{-5} \mathrm{~mol} / \mathrm{L}\right)=0.12$ and $I_{2}$ for $\mathrm{Zn}^{2+}(1.04 \times$ $\left.10^{-4} \mathrm{~mol} / \mathrm{L}\right)=0.21$.

The results are given in Table 3.

$S_{I}$ value is found to be greater than one, indicating the synergistic effect existing between $\mathrm{Zn}^{2+}$ of concentrations 5.2 $\times 10^{-5} \mathrm{~mol} / \mathrm{L}$ and $1.04 \times 10^{-4} \mathrm{~mol} / \mathrm{L}$ with various concentrations of SHXS. 
TABLE 4: Corrosion parameters of carbon steel immersed in dam water in the presence and absence of inhibitor obtained by polarization method.

\begin{tabular}{lccccrc}
\hline $\begin{array}{l}\text { SHXS } \\
(\mathrm{mol} / \mathrm{L})\end{array}$ & $\begin{array}{c}\mathrm{Zn}^{2+} \\
(\mathrm{mol} / \mathrm{L})\end{array}$ & $\begin{array}{c}E_{\text {corr }} \\
\mathrm{mV} \text { versus SCE }\end{array}$ & $\begin{array}{c}I_{\text {corr }} \\
\mathrm{A} / \mathrm{cm}^{2}\end{array}$ & $\begin{array}{c}b_{a} \\
\mathrm{mV} / \mathrm{dec}\end{array}$ & $\begin{array}{c}b_{c} \\
\mathrm{mV} / \mathrm{dec}\end{array}$ & $\begin{array}{c}\mathrm{LPR} \\
\Omega \mathrm{cm}^{2}\end{array}$ \\
\hline 0 & 0 & -494 & $2.66 \times 10^{-6}$ & 166 & 203 & $2.05 \times 10^{4}$ \\
$1.35 \times 10^{-3}$ & $1.04 \times 10^{-4}$ & -572 & $5.31 \times 10^{-7}$ & 178 & 157 & $7.52 \times 10^{4}$ \\
\hline
\end{tabular}

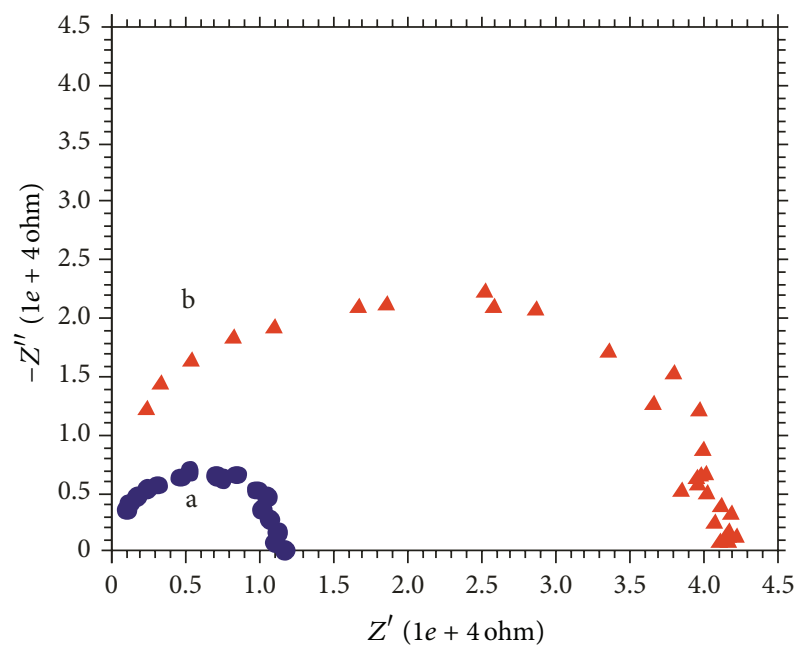

Figure 2: AC impedance spectra of carbon steel immersed in various test solutions. (a) Dam water. (b) Dam water containing 1.35 $\times 10^{-3} \mathrm{~mol} / \mathrm{L}$ of SHXS and $1.04 \times 10^{-4} \mathrm{~mol} / \mathrm{L}$ of $\mathrm{Zn}^{2+}$.

3.2. Analysis of Polarization Curves. Figure 1 represents the potentiodynamic polarization curves of carbon steel in dam water in the absence and presence of the inhibitor system. The cathodic branch represents the oxygen reduction reaction, while the anodic branch represents the iron dissolution reaction. The electrochemical parameters such as corrosion potential $\left(E_{\text {corr }}\right)$, corrosion current $\left(I_{\text {corr }}\right)$, Tafel slopes $\left(b_{a}\right.$ and $b_{c}$ ), and linear polarization resistance (LPR) are given in Table 4.

When carbon steel is immersed in dam water, the corrosion potential is $-494 \mathrm{mV}$ versus SCE. The formulation consisting of SHXS $\left(1.35 \times 10^{-3} \mathrm{~mol} / \mathrm{L}\right)-\mathrm{Zn}^{2+}\left(1.04 \times 10^{-4} \mathrm{~mol} / \mathrm{L}\right)$ shifts the corrosion potential to $-572 \mathrm{mV}$ versus SCE. It is observed that the corrosion potential is shifted to the cathodic side. It is also observed that the shift in the cathodic slope (from $203 \mathrm{mV} / \mathrm{dec}$ to $157 \mathrm{mV} / \mathrm{dec}$ ) is higher than the shift in the anodic slope (from $166 \mathrm{mV} / \mathrm{dec}$ to $178 \mathrm{mV} / \mathrm{dec}$ ). Hence, it can be said that the inhibitor system predominantly controls the cathodic reaction [16]. The corrosion current value and LPR value for dam water are $2.66 \times 10^{-6} \mathrm{~A} / \mathrm{cm}^{2}$ and $2.05 \times$ $10^{4} \Omega \mathrm{cm}^{2}$.

For the formulation of SHXS $\left(1.35 \times 10^{-3} \mathrm{~mol} / \mathrm{L}\right)-\mathrm{Zn}^{2+}$ $\left(1.04 \times 10^{-4} \mathrm{~mol} / \mathrm{L}\right)$, the corrosion current value has decreased to $5.31 \times 10^{-7} \mathrm{~A} / \mathrm{cm}^{2}$, and the LPR value has increased to $7.52 \times$ $10^{4} \Omega \mathrm{cm}^{2}$. The fact that the LPR value increases with decrease in corrosion current indicates adsorption of the inhibitor on the metal surface to block the active sites and inhibit corrosion and reduce the corrosion rate [17, 18].

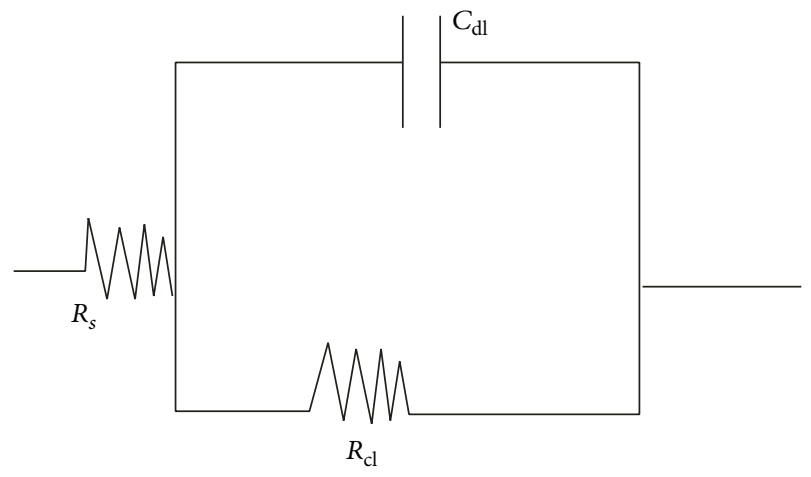

Figure 3: Equivalent electrical circuit diagram. $R_{s}=$ solution resistance. $R_{\mathrm{ct}}=$ charge transfer resistance. $C_{\mathrm{dl}}=$ double layer capacitance.

3.3. Analysis of AC Impedance Spectra. AC impedance spectra have been used to detect the formation of film on the metal surface. If a protective film is formed, the charge transfer resistance $\left(R_{t}\right)$ increases and double layer capacitance $\left(C_{\mathrm{dl}}\right)$ value decreases $[19,20]$. Nyquist representations of carbon steel in dam water in the absence and presence of the inhibitor system are shown in Figure 2.

It is clear from the plots that the impedance response of carbon steel was significantly changed after addition of the inhibitors. The impedance diagrams obtained have an almost semicircular appearance. This indicates that the corrosion of carbon steel in aqueous solution is mainly controlled by a charge transfer process [21]. The deviation from the perfect semicircle shape (depression) is due to the frequency dispersion of interfacial impedance. This anomalous behavior is generally attributed to the inhomogeneity of the metal surface arising from surface roughness or interfacial phenomena [22]. The AC impedance parameters, namely, charge transfer resistance $\left(R_{t}\right)$ and double layer capacitance $\left(C_{\mathrm{dl}}\right)$, are given in Table 5.

When carbon steel is immersed in dam water, $R_{t}$ value is $1.08 \times 10^{4} \Omega \mathrm{cm}^{2}$ and $C_{\mathrm{dl}}$ value is $8.36 \times 10^{-10} \mathrm{~F} / \mathrm{cm}^{2}$. When SHXS $\left(1.35 \times 10^{-3} \mathrm{~mol} / \mathrm{L}\right)-\mathrm{Zn}^{2+}\left(1.04 \times 10^{-4} \mathrm{~mol} / \mathrm{L}\right)$ are added to dam water, $R_{t}$ value increases from $1.08 \times$ $10^{4} \Omega \mathrm{cm}^{2}$ to $3.93 \times 10^{4} \Omega \mathrm{cm}^{2}$ and the $C_{\mathrm{dl}}$ decreases from $8.36 \times 10^{-10} \mathrm{~F} / \mathrm{cm}^{2}$ to $2.30 \times 10^{-10} \mathrm{~F} / \mathrm{cm}^{2}$. This suggests that a protective film is formed on the surface of the metal. Results obtained from impedance measurements can be interpreted in terms of the equivalent circuit of the electrical double-layer presented in Figure 3, which was used previously to model other interaction involving metal/solutions interface $[23,24]$. 
TABLE 5: Impedance parameters of carbon steel in dam water in the presence and absence of inhibitor obtained by AC impedance method.

\begin{tabular}{lccc}
\hline $\begin{array}{l}\text { SHXS } \\
(\mathrm{mol} / \mathrm{L})\end{array}$ & $\begin{array}{c}\mathrm{Zn}^{2+} \\
(\mathrm{mol} / \mathrm{L})\end{array}$ & $\begin{array}{c}R_{t} \\
\Omega \mathrm{cm}^{2}\end{array}$ & $\begin{array}{c}C_{\mathrm{dl}} \\
\mathrm{F} / \mathrm{cm}^{2}\end{array}$ \\
\hline 0 & 0 & $1.08 \times 10^{4}$ & $8.36 \times 10^{-10}$ \\
$1.35 \times 10^{-3}$ & $1.04 \times 10^{-4}$ & $3.93 \times 10^{4}$ & $2.30 \times 10^{-10}$ \\
\hline
\end{tabular}

This type of circuit is known as Randle circuit. Many authors also suggested Randle circuit for similar graphs $[25,26]$.

3.4. Analysis of FTIR Spectra. Earlier researchers have confirmed that FTIR spectrometer is a powerful instrument that can be used to determine the type of bonding for organic inhibitors adsorbed on the metal surface [27]. FTIR spectra have been used to analyze the protective film formed on metal surface. FTIR spectrum of pure SHXS is given in Figure 4(a). The FTIR spectrum of the film formed on the metal surface after immersion in the dam water for one day containing $250 \mathrm{ppm}$ of SHXS and $30 \mathrm{ppm}$ of $\mathrm{Zn}^{2+}$ is shown in Figure 4(b). The $\mathrm{S}=\mathrm{O}$ stretching frequency has decreased from $1193 \mathrm{~cm}^{-1}$ to $1120 \mathrm{~cm}^{-1}$. This indicates that the oxygen atom of $\mathrm{S}=\mathrm{O}$ group has coordinated with $\mathrm{Fe}^{2+}$ formed on the metal surface resulting in the formation of $\mathrm{Fe}^{2+}$-SHXS complex on the anodic sites of the metal surface. The peak at $1386 \mathrm{~cm}^{-1}$ is due to $\mathrm{Zn}-\mathrm{O}$ stretching. The stretching frequency due to $-\mathrm{OH}$ appears at $3463 \mathrm{~cm}^{-1}$. So, it is concluded that $\mathrm{Zn}(\mathrm{OH})_{2}$ is formed on cathodic sites of the metal surface [28].

3.5. Atomic Force Microscopy Characterization. AFM is a powerful technique to investigate the surface morphology at nano- to microscale and has become a new choice to study the influence of inhibitor on the generation and the progress of the corrosion at the metal/solution interface [2932]. The three-dimensional (3D) AFM morphology and the AFM cross-sectional profile for polished carbon steel surface (reference sample), carbon steel surface immersed in dam water (blank sample), and carbon steel surface immersed in dam water containing SHXS $\left(1.35 \times 10^{-3} \mathrm{~mol} / \mathrm{L}\right)-\mathrm{Zn}^{2+}(1.04 \times$ $10^{-4} \mathrm{~mol} / \mathrm{L}$ ) are shown in Figures 5 and 6 .

3.6. Root-Mean-Square Roughness, Average Roughness, and Peak-to-Valley Value. AFM image analysis was performed to obtain the average roughness, $R_{a}$, (the average deviation of all points roughness profile from a mean line over the evaluation length), root-mean-square roughness, $R_{q}$, (the average of the measured height deviations taken within the evaluation length and measured from the mean line), and the maximum peak-to-valley $(P-V)$ height values (largest single peak-tovalley height in five adjoining sampling heights) [29]. Table 6 is a summary of $\left(R_{q}\right),\left(R_{a}\right)$, and $(P-V)$ value for carbon steel surface immersed in different environment.

In Figures 5(a) and 6(a) the surface topography of uncorroded metal surface is shown. The value of $R_{q}, R_{a}$, and

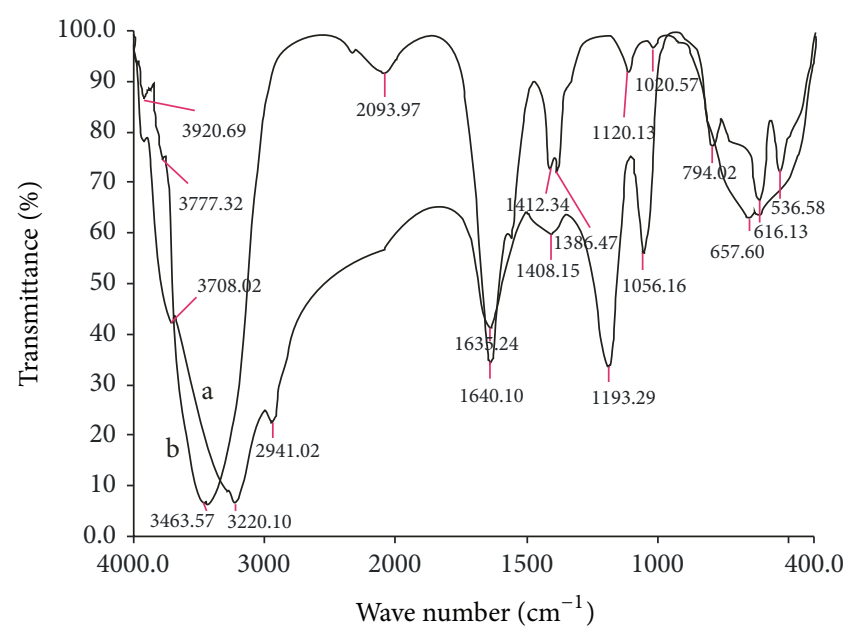

FIGURE 4: (a) FTIR spectrum of pure sodium hexanesulphonate. (b) FTIR spectrum of film formed on metal surface after immersion in dam water containing $1.35 \times 10^{-3} \mathrm{~mol} / \mathrm{L}$ of SHXS and $1.04 \times$ $10^{-4} \mathrm{~mol} / \mathrm{L}$ of $\mathrm{Zn}^{2+}$.

$P-V$ height for the polished carbon steel surface (reference sample) is $4.33 \mathrm{~nm}, 3.41 \mathrm{~nm}$, and $35.28 \mathrm{~nm}$, respectively. The slight roughness observed on the polished carbon steel surface is due to atmospheric corrosion.

Figures 5(b) and 6(b) show the pitted, corroded metal surface in the absence of the inhibitor immersed in dam water. The $\left(R_{q}\right),\left(R_{a}\right)$, and $(P-V)$ height values for the carbon steel surface are $31.9 \mathrm{~nm}, 24.9 \mathrm{~nm}$, and $420.3 \mathrm{~nm}$, respectively. These data suggest that carbon steel surface immersed in dam water has a greater surface roughness than the polished metal surface, which shows that the unprotected carbon steel surface is rougher and is due to the corrosion of the carbon steel in dam water environment.

Figures 5(c) and 6(c) show the steel surface after immersion in dam water containing SHXS $\left(1.35 \times 10^{-3} \mathrm{~mol} / \mathrm{L}\right)$ $\mathrm{Zn}^{2+}\left(1.04 \times 10^{-4} \mathrm{~mol} / \mathrm{L}\right)$. The $\left(R_{q}\right),\left(R_{a}\right)$, and $(P-V)$ height values for the carbon steel surface are $4.38 \mathrm{~nm}, 3.71 \mathrm{~nm}$, and $27.21 \mathrm{~nm}$, respectively. The $\left(R_{q}\right),\left(R_{a}\right)$, and $(P-V)$ height values are considerably less in the inhibited environment compared to the uninhibited environment. These parameters confirm that the surface is smoother. The smoothness of the surface is due to the formation of a compact protective film of $\mathrm{Fe}^{2+}$-SHXS complex and $\mathrm{Zn}(\mathrm{OH})_{2}$ on the metal surface thereby inhibiting the corrosion of carbon steel [29].

3.7. Mechanism of Corrosion Inhibition. With these discussions, a mechanism may be proposed for the corrosion inhibition of carbon steel immersed in dam water containing SHXS $\left(1.35 \times 10^{-3} \mathrm{~mol} / \mathrm{L}\right)-\mathrm{Zn}^{2+}\left(1.04 \times 10^{-4} \mathrm{~mol} / \mathrm{L}\right)$.

When the formulation consists of SHXS $(1.35 \times$ $\left.10^{-3} \mathrm{~mol} / \mathrm{L}\right)-\mathrm{Zn}^{2+}\left(1.04 \times 10^{-4} \mathrm{~mol} / \mathrm{L}\right)$ in dam water, there is formation of SHXS- $\mathrm{Zn}^{2+}$ complex in solution. 
TABLE 6: AFM data for carbon steel surface immersed in inhibited and uninhibited environment.

\begin{tabular}{lccc}
\hline Samples & $\begin{array}{c}\text { RMS }\left(R_{q}\right) \\
\text { roughness } \\
(\mathrm{nm})\end{array}$ & $\begin{array}{c}\text { Average }\left(R_{a}\right) \\
\text { roughness } \\
(\mathrm{nm})\end{array}$ & $\begin{array}{c}\text { Maximum peak-to-valley } \\
\text { height }(\mathrm{nm})\end{array}$ \\
\hline $\begin{array}{l}\text { 1. Polished carbon steel } \\
\text { 2. Carbon steel immersed in dam water (blank) }\end{array}$ & 4.33 & 3.41 & 35.28 \\
$\begin{array}{l}\text { 3. Carbon steel immersed in dam water + SHXS }\left(1.35 \times 10^{-3} \mathrm{~mol} / \mathrm{L}\right)+\mathrm{Zn}^{2+} \\
\left(1.04 \times 10^{-4} \mathrm{~mol} / \mathrm{L}\right)\end{array}$ & 31.9 & 24.9 & 420.3 \\
\hline
\end{tabular}

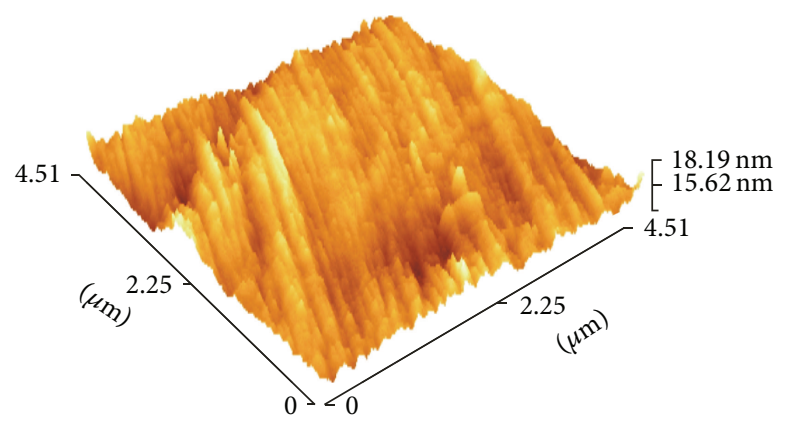

(a)

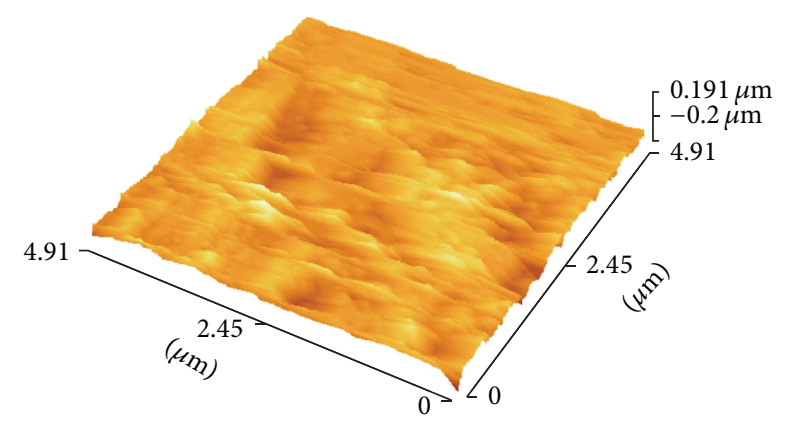

(b)

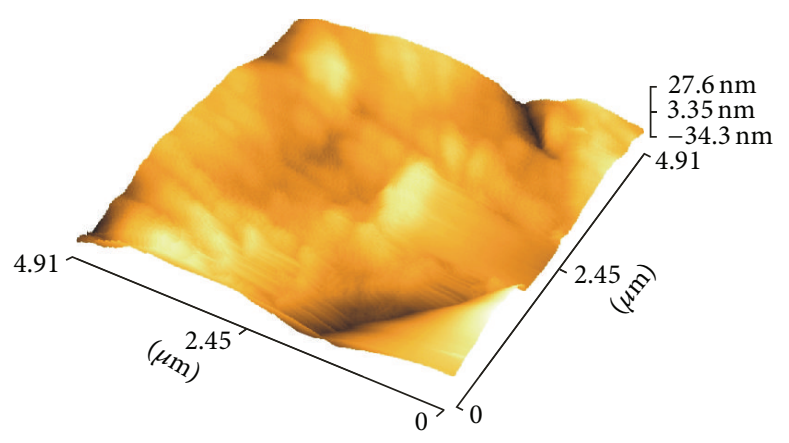

(c)

Figure 5: Three-dimensional AFM images of the surface of (a) polished carbon steel (control); (b) carbon steel immersed in dam water (blank); (c) carbon steel immersed in dam water containing $1.35 \times 10^{-3} \mathrm{~mol} / \mathrm{L}$ of SHXS and $1.04 \times 10^{-4} \mathrm{~mol} / \mathrm{L}$ of $\mathrm{Zn}^{2+}$.

(1) When carbon steel is immersed in this solution SHXS- $\mathrm{Zn}^{2+}$ complex diffuses from the bulk of the solution towards the metal surface.

(2) SHXS- $\mathrm{Zn}^{2+}$ complex is converted into SHXS-Fe ${ }^{2+}$ complex on the anodic sites of the metal surface with the release of $\mathrm{Zn}^{2+}$ ion:

$$
\mathrm{Zn}^{2+}-\mathrm{SHXS}+\mathrm{Fe}^{2+} \longrightarrow \mathrm{Fe}^{2+}-\mathrm{SHXS}+\mathrm{Zn}^{2+}
$$

The released $\mathrm{Zn}^{2+}$ combines with $\mathrm{OH}^{-}$to form $\mathrm{Zn}(\mathrm{OH})_{2}$ on the cathodic sites of the metal surface.

$$
\mathrm{Zn}^{2+}+2 \mathrm{OH}^{-} \longrightarrow \mathrm{Zn}(\mathrm{OH})_{2} \downarrow
$$

(3) Thus the protective film consists of SHXS-Fe ${ }^{2+}$ complex and $\mathrm{Zn}(\mathrm{OH})_{2}$.
(4) This accounts for the synergistic effect of SHXS- $\mathrm{Zn}^{2+}$ system.

\section{Conclusions}

The present study leads to the following conclusions.

The inhibition efficiency (IE) of SHXS in controlling corrosion of carbon steel immersed in dam water in the absence and presence of $\mathrm{Zn}^{2+}$ has been evaluated by weight loss method. The formulation consisting of $1.35 \times 10^{-3} \mathrm{~mol} / \mathrm{L}$ of SHXS and $1.04 \times 10^{-4} \mathrm{~mol} / \mathrm{L}$ of $\mathrm{Zn}^{2+}$ has $83 \%$ IE. Polarization study reveals that $\mathrm{SHXS}-\mathrm{Zn}^{2+}$ system controls the cathodic reaction predominantly. AC impedance spectra and AFM study reveal that a compact protective film is formed on the metal surface. 


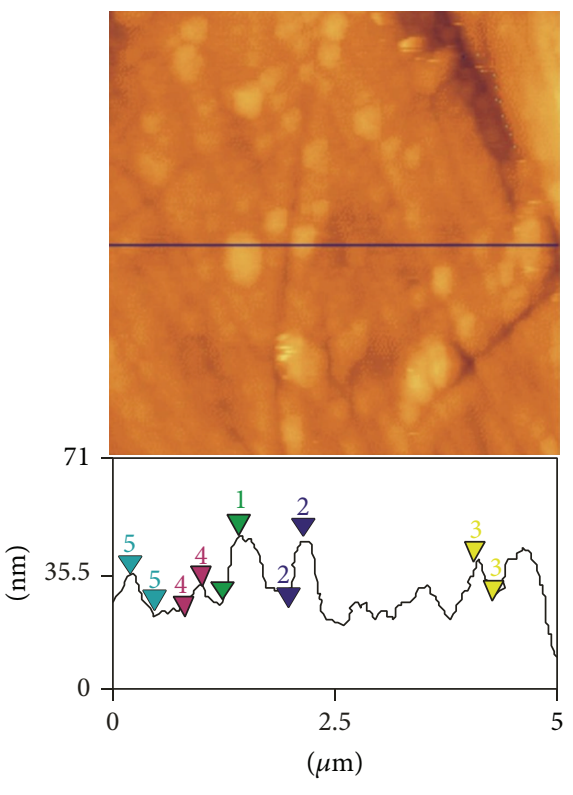

(a)

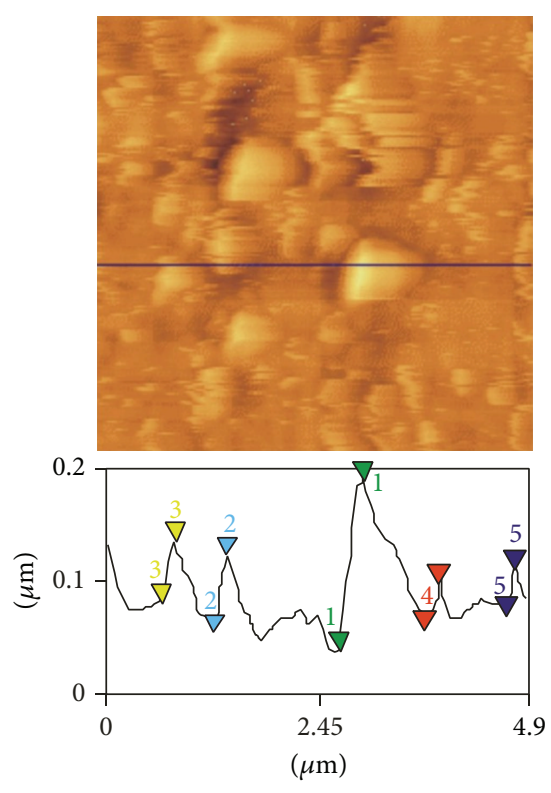

(b)

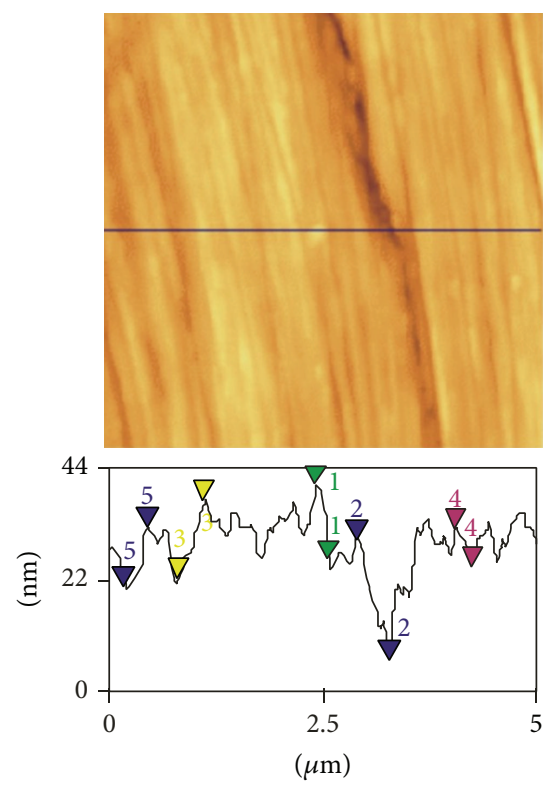

(c)

FIGURE 6: AFM cross-sectional images of the surface of (a) polished carbon steel (control); (b) carbon steel immersed in dam water (blank);

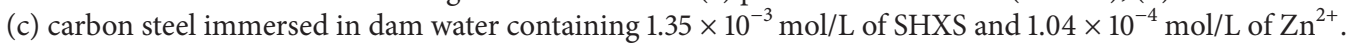

\section{Conflict of Interests}

The authors declare that there is no conflict of interests regarding the publication of this paper.

\section{Acknowledgment}

The authors are thankful to their respective managements for their support and encouragement.

\section{References}

[1] Z. B. Vendrame and R. S. Gonçalves, "Electrochemical evidences of the inhibitory action of propargyl alcohol on the electrooxidation of nickel in sulfuric acid," Journal of the Brazilian Chemical Society, vol. 9, no. 5, pp. 441-448, 1998.

[2] R. S. Gonçalves and L. D. Mello, "Electrochemical investigation of ascorbic acid adsorption on low-carbon steel in $0.50 \mathrm{M}$ $\mathrm{Na}_{2} \mathrm{SO}_{4}$ solutions," Corrosion Science, vol. 43, no. 3, pp. 457-470, 2001.

[3] R. S. Gonçalves, D. S. Azambuja, and A. M. Serpa Lucho, "Electrochemical studies of propargyl alcohol as corrosion inhibitor for nickel, copper, and copper/nickel 955/45 alloy," Corrosion Science, vol. 44, no. 3, pp. 467-479, 2002.

[4] W. X. Oliver and R. S. Gonclaves, "Electrochemical evidence of the protection efficiency of Furfural on the corrosion process of low carbon steel in ethanolic medium," Journal of Brazil Chemical Society, vol. 3, pp. 92-94, 1992.

[5] I. B. Obot, N. O. Obi-Egbedi, and S. A. Umoren, "Adsorption characteristics and corrosion inhibitive properties of clotrimazole for aluminium corrosion in hydrochloric acid," International Journal of Electrochemical Science, vol. 4, no. 6, pp. 863877, 2009.
[6] L. M. Vračar and D. M. Draži, "Adsorption and corrosion inhibitive properties of some organic molecules on iron electrode in sulfuric acid," Corrosion Science, vol. 44, no. 8, pp. 16691680, 2002.

[7] D. Prakash, R. K. Singh, and R. Kumari, "Corrosion inhibition of mild steel in $20 \% \mathrm{HCl}$ by some organic compounds," Indian Journal of Chemical Technology, vol. 13, no. 6, pp. 555-560, 2006.

[8] R. Manickavasagam, K. J. Karthik, M. Paramasivam, and S. V. Iyer, "Poly(styrene sulphonic acid)-doped polyaniline as an inhibitor for the corrosion of mild steel in hydrochloric acid," Anti-Corrosion Methods and Materials, vol. 49, no. 1, pp. 19-26, 2002.

[9] T. A. Aliev, "Influence of salts of alkylphenol sulfonic acid on the corrosion of St3 steel in HCl-kerosene systems," Materials Science, vol. 44, no. 5, pp. 665-671, 2008.

[10] P. Shakkthivel and T. Vasudevan, "Acrylic acid-diphenylamine sulphonic acid copolymer threshold inhibitor for sulphate and carbonate scales in cooling water systems," Desalination, vol. 197, no. 1-3, pp. 179-189, 2006.

[11] G. Wranglen, "Synergistic effect of 2-chloroethyl phosphonic acid and Zn2+," in Introduction To Corrosion and Protection of Metals, p. 236, Chapman and Hall, London, UK, 1985.

[12] M. G. Fontana, Corrosion Engineering, McGraw-Hill, New Delhi, India, 3rd edition, 2006.

[13] T. Umamathi, J. A. Selvi, S. A. Kanimozhi, S. Rajendran, and A. J. Amalraj, "Effect of $\mathrm{Na}_{3} \mathrm{PO}_{4}$ on the corrosion inhibition efficiency of EDTA: $\mathrm{Zn}^{2+}$ system for carbon steel in aqueous solution," Indian Journal of Chemical Technology, vol. 15, no. 6, pp. 560-565, 2008.

[14] S. Rajendran, S. Shanmugapriya, T. Rajalakshmi, and A. J. Amal Raj, "Corrosion inhibition by an aqueous extract of rhizome powder," Corrosion, vol. 61, no. 7, pp. 685-692, 2005.

[15] K. Anuradha, R. Vimala, B. Narayanasamy, J. A. Selvi, and S. Rajendran, "Corrosion inhibition of carbon steel in low chloride media by an aqueous extract of Hibiscus rosa-sinensis Linn," 
Chemical Engineering Communications, vol. 195, no. 3, pp. 352366, 2008.

[16] C. M. Anbarasi and S. Rajendran, "Inhibition of corrosion of carbon steel by Heptane sulphonicacid: $\mathrm{Zn}^{2+}$ system," Journal of Electrchemical Science and Engineering, vol. 2, no. 1, pp. 1-18, 2012.

[17] C. M. Anbarasi, S. Rajendran, B. Narayanasamy, and A. Krishnaveni, "Surface analysis of inhibitor film formed by Butane sulphonic acid: $\mathrm{Zn}^{2+}$ system on carbon steel in aqueous medium," Asian Journal of Chemistry, vol. 24, pp. 5029-5034, 2012.

[18] J. Sathiyabama, S. Rajendran, and J. Arockia Selvi, "Eriochrome Black T as corrosion inhibitor for carbon steel in well water," Bulletin of Electrochemistry, vol. 22, pp. 363-370, 2006.

[19] J. Arockia Selvi, S. Rajendran, and J. Jeyasundari, "Analysis of nano film by atomic force microscopy", Zastita Materijala, vol. 50, pp. 91-98, 2009.

[20] V. Johnsirani, J. Sathiyabama, S. Rajendran, and A. Suriya Prabha, "Inhibitory mechanism of carbon steel corrosion in sea water by an aqueous extract of henna leaves," ISRN Corrosion, vol. 2012, Article ID 574321, 9 pages, 2012.

[21] S. Rajendrran, M. Agasta, R. Bama Devi, B. Shyamla Devi, K. Rajam, and J. Jeyasundari, "corrosion inhibition of aqueous extract of Henna leaves," Zastita Materijala, vol. 50, pp. 77-84, 2009.

[22] S. Rajendran, M. Manivannan, J. Wilson Sahayaraj et al., "Corrosion behavior of aluminium in methyl orange solution at $\mathrm{pH}$ 11," Transactions of the SAEST, vol. 41, no. 2, pp. 63-67, 2006.

[23] F. N. Grosser and R. S. Gonçalves, "Electrochemical evidence of caffeine adsorption on zinc surface in ethanol," Corrosion Science, vol. 50, no. 10, pp. 2934-2938, 2008.

[24] S. Martinez and M. Metikoš-Huković, "A nonlinear kinetic model introduced for the corrosion inhibitive properties of some organic inhibitors," Journal of Applied Electrochemistry, vol. 33, no. 12, pp. 1137-1142, 2003.

[25] M. Elayyachy, A. El Idrissi, and B. Hammouti, "New thiocompounds as corrosion inhibitor for steel in $1 \mathrm{M} \mathrm{HCl}$," Corrosion Science, vol. 48, no. 9, pp. 2470-2479, 2006.

[26] S. K. Shukla and M. A. Quraishi, "4-Substituted anilinomethylpropionate: new and efficient corrosion inhibitors for mild steel in hydrochloric acid solution," Corrosion Science, vol. 51, no. 9, pp. 1990-1997, 2009.

[27] A. Lalitha, S. Ramesh, and S. Rajeswari, "Surface protection of copper in acid medium by azoles and surfactants," Electrochimica Acta, vol. 51, no. 1, pp. 47-55, 2005.

[28] R. M. Silverstein and X. Francis, Webster Spectrometric Identification of Organic Compounds, John Wiley and Sons, 6th edition, 2007.

[29] C. M. Anbarasi and S. Rajendran, "Surface protection of carbon steel by butanesulphonic acid-zinc ion system," Research Journal of Chemical Sciences, vol. 2, no. 12, pp. 21-26, 2012.

[30] B. Sherine, A. J. Abdul Nasser, and S. Rajendran, "Inhibitive action of hydroquinone: $\mathrm{Zn}^{2+}$ System in controlling the corrosion of carbon steel in well water," International Journal of Engineering Science and Technology, vol. 2, pp. 341-357, 2010.

[31] A. K. Singh and M. A. Quraishi, "Investigation of the effect of disulfiram on corrosion of mild steel in hydrochloric acid solution," Corrosion Science, vol. 53, no. 4, pp. 1288-1297, 2011.

[32] B. Wang, M. Du, J. Zhang, and C. J. Gao, "Electrochemical and surface analysis studies on corrosion inhibition of Q235 steel by imidazoline derivative against $\mathrm{CO}_{2}$ corrosion," Corrosion Science, vol. 53, no. 1, pp. 353-361, 2011. 

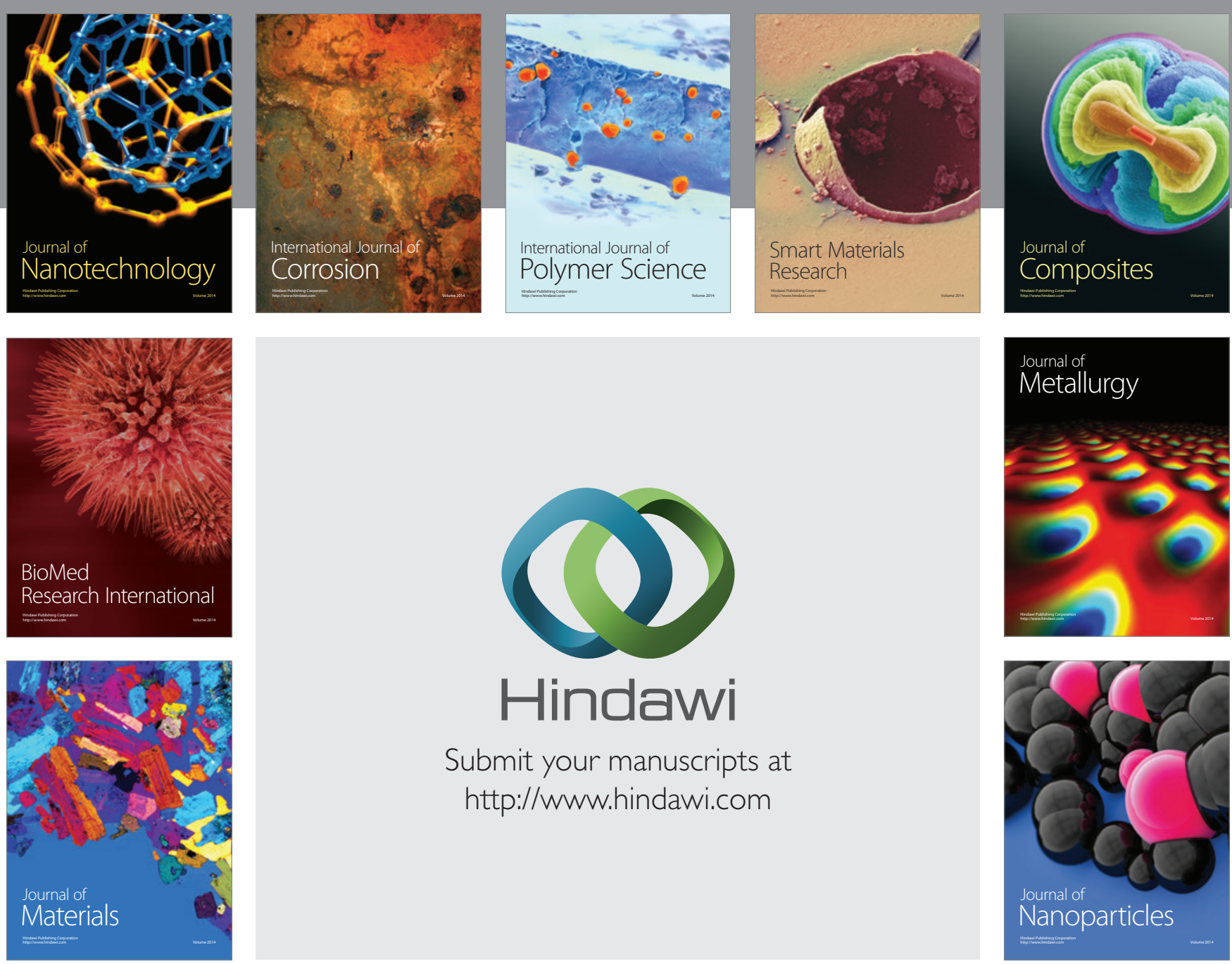

Submit your manuscripts at http://www.hindawi.com
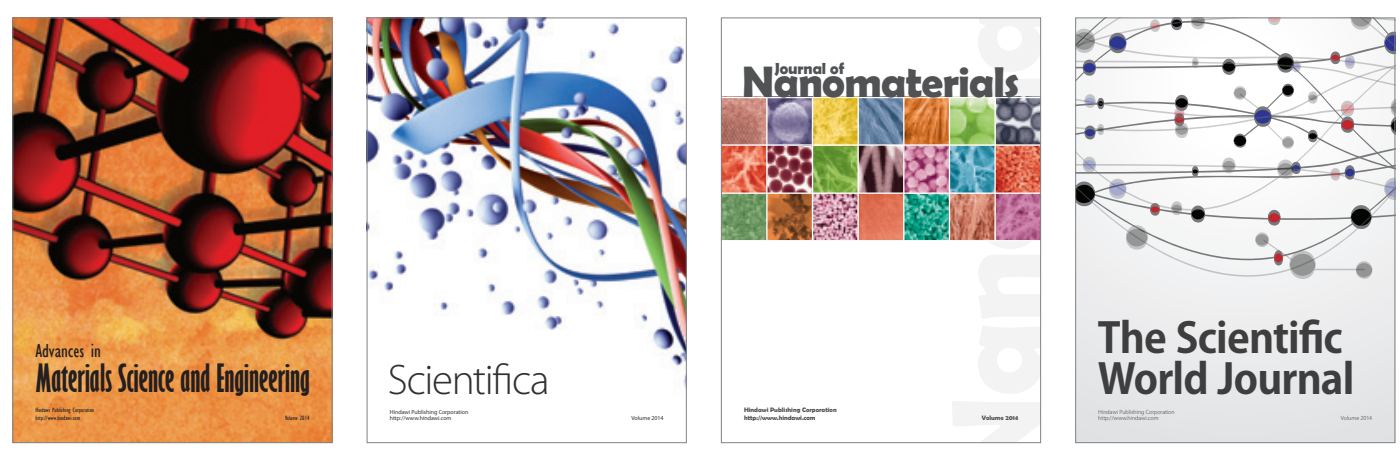

\section{The Scientific World Journal}
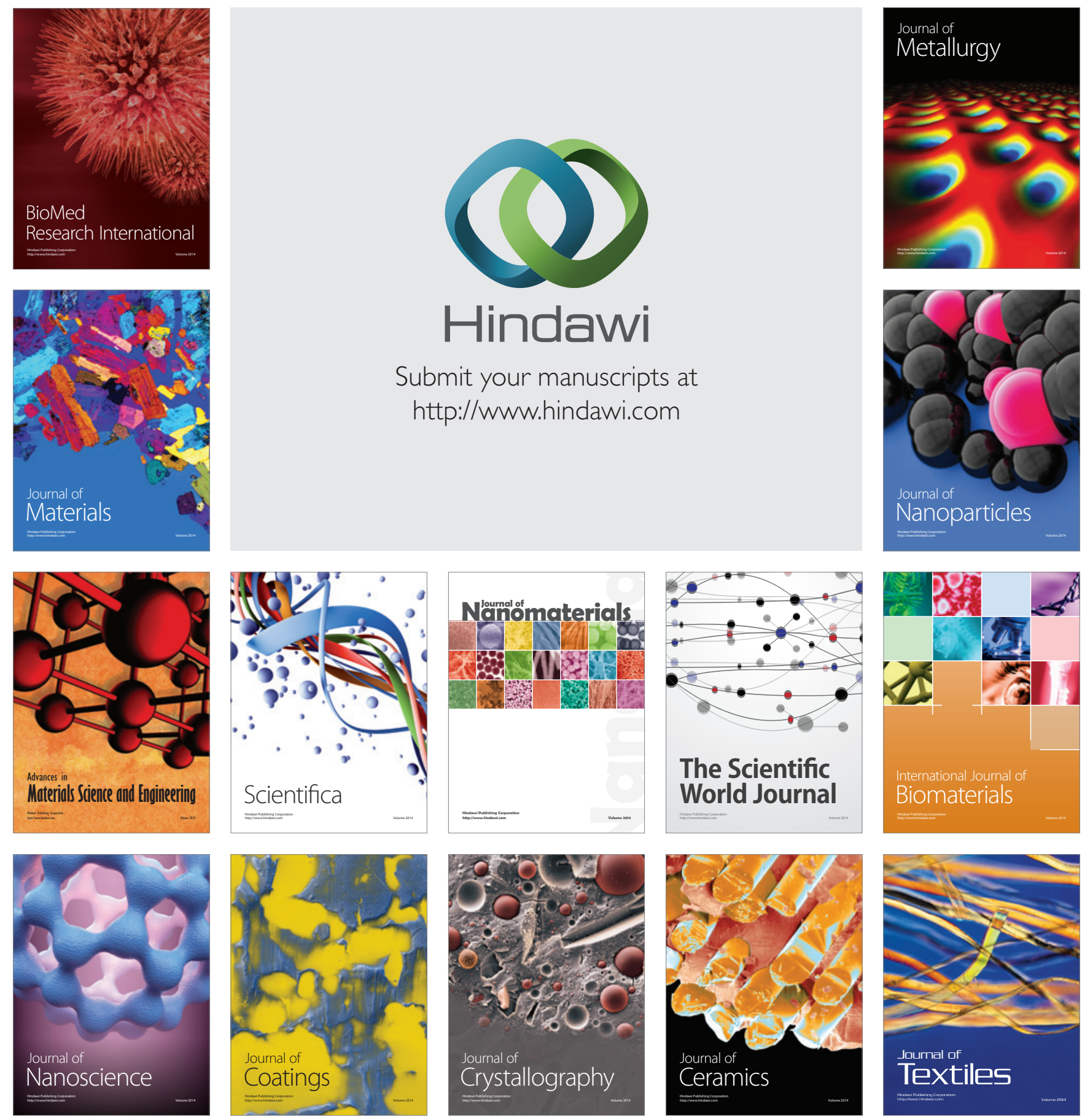